\title{
Communication Process for the Strengthening of the Care of the Minor in a Pediatric Unit
}

\author{
Anderson Díaz-Pérez ${ }^{1,2}$, Zuleima Yáñez-Torregroza ${ }^{1}$, Jaime Lorduy Gómez ${ }^{2}$, \\ Idelsy Carrillo-Suárez ${ }^{3} \&$ Shirley Garcia Mora ${ }^{3}$ \\ ${ }^{1}$ Universidad Simón Bolívar, Departamento de Ciencias Sociales y Humanas, Barranquilla, Colombia \\ ${ }^{2}$ Corporación Universitaria Rafael Núñez, Faculty of Health Sciences, Cartagena de Indias, Colombia \\ ${ }^{3}$ Universidad Popular del Cesar, Faculty of Health Sciences, Valledupar, Colombia \\ Correspondence: Anderson Díaz-Pérez, Simón Bolívar University, Faculty of Health Sciences, Barranquilla, \\ Colombia, Faculty de Basic and Orcid: https://orcid.org/0000-0001-8941-5592, Barranquilla, Colombia. ORCID: \\ http//:orcid.org/0000-0003-2448-0953. E-mail: ander2711@gmail.com
}

Received: July 19, 2018 Accepted: August 24, 2018 Online Published: September 10, 2018

doi:10.5539/gjhs.v10n10p84 URL: https://doi.org/10.5539/gjhs.v10n10p84

\begin{abstract}
Introduction: The reflection about the elements of communication that health professionals use strengthens the empathic relationship and therefore the actions that seek self-care in patients. Nursing schools must teach how to acquire competences from what should be (moral) to fully consider the emotions and needs of hospitalized children so that they can attend to the call of care. Nursing should tend to social and communication skills to offer a humanized care when children appeal to crying, to silence, to play, to attract attention.
\end{abstract}

Objective: Propose a framework of moral management of communication from the design of a functional communication structure model for the pediatric patient to come to the call of their care in a positive way.

Methodology: Nature of qualitative study of descriptive type and symbolic interactionism (perceptual regression). The population was 44 nurses. The data was obtained by interviews analyzed by the STATGRAPHICS XVII Centurión Plus ${ }^{\circledR}$ and Atlas Ti $8.0{ }^{\circledR}$ programs.

Conclusion: The practices of nurses respond to the dynamics so that the child comes to the care when they are aware of the purpose of communication in strengthening the moral development of the child. A model of functional communication structure for pediatric patient care adjusted to the axioms of Paul Watzlawick is proposed.

Keywords: communication, health, care, nursing, minor, children, empathy, pediatrics

\section{Introduction}

Nursing profession has always sought on the philosophy and moral of its actions the aesthetic and ethical elements, but also those personal elements that contribute to improving the quality of care offered, which cannot be conceived without the full understanding of the nurse-patient relationship specially when these are children (de Villalobos \& Mercedes, 2005) where the power relationship should be [Nurse-Minor-Guardian].

The ethics of care provides moral elements that must be motivated by conscious or unconscious patient's request, as Paul Watzlawick himself describes it, in one of his axioms: the digital (verbal) and the analog (non-verbal), even in silence, even in silence (Arango, Rodríguez, Benavides, \& Ubaque, 2016; Watzlawick, Bavelas, \& Jackson, 2011; Watzlawick \& Jackson, 2010).

Healthcare as communication requires of human interaction, that is to say, a world in which nurses are responsible for the recognition, protection and well-being of the other, configuring an ethically responsible world (García, 2004; Garcia Reza, Iniesta, del Carmen, Solano Solano, \& Guadarrama Perez, n. d.; Velásquez, 2017).

It is of great concern on the part of health professionals, especially nurses, the way and approach of how to communicate with the patient, especially when involves to gain the trust and empathy of children (Diaz-Perez et al., 2018; Torres \& Campos, 2010). This type of problem has been analyzed from the curricular design perspective in nursing schools, in which the distance between the curriculum and professional practice has been described, when implementing educational programs with content in morals and values that contribute to raise the level of moral 
development in vocational training (Diaz-Perez et al., 2018; Silver, Ford, \& Steady, 1967; Well, First, Dignity, it Out, \& Training, 1993), not to mention the lack of training on communication theories that nursing professionals as care managers require to achieve good quality in their relationships with the development of better social skills (Maldonado, 2012; Pérez, Puerta, \& Cataño, 2014).

Authors as (Pérez et al., 2014; Riley, 2015; Sheldon, Barrett, \& Ellington, 2006) mention the communication difficulty that nurses have, defining that the problem is located at the moment of explaining the diagnosis or clinical situations, as well as understanding patients fears, patient's relatives emotions; nurses' emotions when caring for a child must face difficult and even aggressive behavior, nurses need to identify the emotions of patients which is the most variable and difficult when establishing communication channels.

The purpose of the nursing professional, in addition to providing good care, is to achieve the empathy and trust of pediatric patients, in order to achieve the maximum possible cooperation of the child as well as the parents, who need to understand everything concerning the state of the child, for this the nurse must recognize the elements for a good communication, taking into account evaluation and analysis tools such as: to evaluate the cognitive aspects of understanding the reality that surrounds the child and the type of communication preferred by the parents (intimate or collective) (Bach \& Grant, 2015; Sheldon et al., 2006; Silver et al., 1967; Sobo, 2004; Tseng et al., 2015; Well et al., 1993); it has been shown that the strategies implemented are insufficient when they underestimate what parents want for the child from their well-being and care perception beyond the nurse's duties (Pérez et al., 2014).

According to (Watzlawick, 1977; Watzlawick et al., 2011), it does not exist the no communication, as one of his axioms refers "the impossibility of communication", since the words and silences themselves convey a message, especially when it is from children perspective, who perceive communication as something further than just simple transmission of information.

In nursing it is essential to establish good communication with the people they take care, since it is a sine qua non condition to be able to offer quality and assertive care that seeks to strengthen elements such as self-care and therefore the autonomy of patients (Bonill de las Nieves, 2008; García-Salido, la Calle, \& González, 2018).

The studies mentioned above refer to determining the patients ability to communicate, but in reality there are very few studies that determine the willingness to listen and explain in a simple and clear way within communication channels that seek to understand the information and getting the pediatric patient to cooperate, is for this reason that the nurse must develop communication skills that go beyond the use of techniques to provide information or give simple orders, because they do not ensure assertive or empathetic communication, neither for the child or the family (Bonill de las Nieves, 2008; Fellowes, Wilkinson, \& Moore, 2008; Sobo, 2004).

\subsection{Objective}

To propose a framework of communication moral management from the design of a functional communication structure model for the pediatric patient to come to the care request in a positive way.

\section{Methodology}

A mixed nature study was proposed from a theoretical and methodological approach, using a descriptive type study with a symbolic interactionism with perceptual regression method. The significance of the meanings that emerge from the behavior, skills and practices of nurses at the moment of communicating and caring for the child from which elements of a system of intersubjective meanings emerge among the nurses, as well as symbols of interaction that relate to the way of perceive the other (Bautista, 2011; Mella, 1998; Pérez et al., 2014). The population was comprised by 44 nurses who work in the pediatric unit of a third level health institution. The questions of the interviews were directed to determine the respect, the interest and the degree of participation, among other fundamental elements of the axioms proposed by Paul Watzlawick.

Data were analyzed with the software STATGRAPHICS XVII ${ }^{\circledR}$ for the development of the process map and its optimization according to the categories levels (nodes).

The software Atlas Ti $8.0 \circledR$ was used for categorization, category crossing and co-occurrence analysis to conceptualize the description of the axioms in actions assumed by the nurse when caring for the child. The study was carried out in 5 phases:

Phase 1. Description and relation of emerging actions with the peripheral and central nodes: the data were taken from the interviews and the observation format. The most important elements that could be considered as nodes that respond to the threshold of the axioms were crossed.

Phase 2. Relationship of the peripheral nodes with the axiomatic central nodes proposed by Paul Watzlawick: 
$1^{\text {st }}$. It is impossible not to communicate. $2^{\text {nd }}$. All communication has a content level and a relationship level, in such a way that the latter classifies the first, and is, therefore, a meta-communication. $3^{\text {rd }}$. The nature of a relationship depends on the gradation that participants make of the communication sequences between them. $4^{\text {th }}$. Human communication involves two modalities: digital and analog. $5^{\text {th }}$. The communicational exchanges can be both symmetrical and complementary.

Phase 3: organizing the categories in relation to the events, the participants, the process, scenarios and situation within the categories of development, moral maturity, and autonomy.

Phase 4: interaction analysis, which its main ontological component was the ability to describe from the objectification, details of how is the interaction, and to be able to explain the fact with logical interpretations from the theoretical and moral concepts involved.

Phase 5: collection, condensation and presentation of information through summaries, codifications, classifications, diagrams, etc., in order to generate a synthesis or grouping of the most significant aspects.

\section{Results}

The creation of the models for the structure diagrams were made from the symbolism framework (symbolic interactionism and perceptual regression), for which the following elements were taken into account:

The formalization of the concepts and categories (nodes): which reveal the actions and perceptions of the nurses at the moment of obtaining the attention and obedience of the child from the framework of analysis of the five (5) axioms proposed by Paul Watzlawick (See Figure 1. Emerging actions in relation to care and communication with the child).

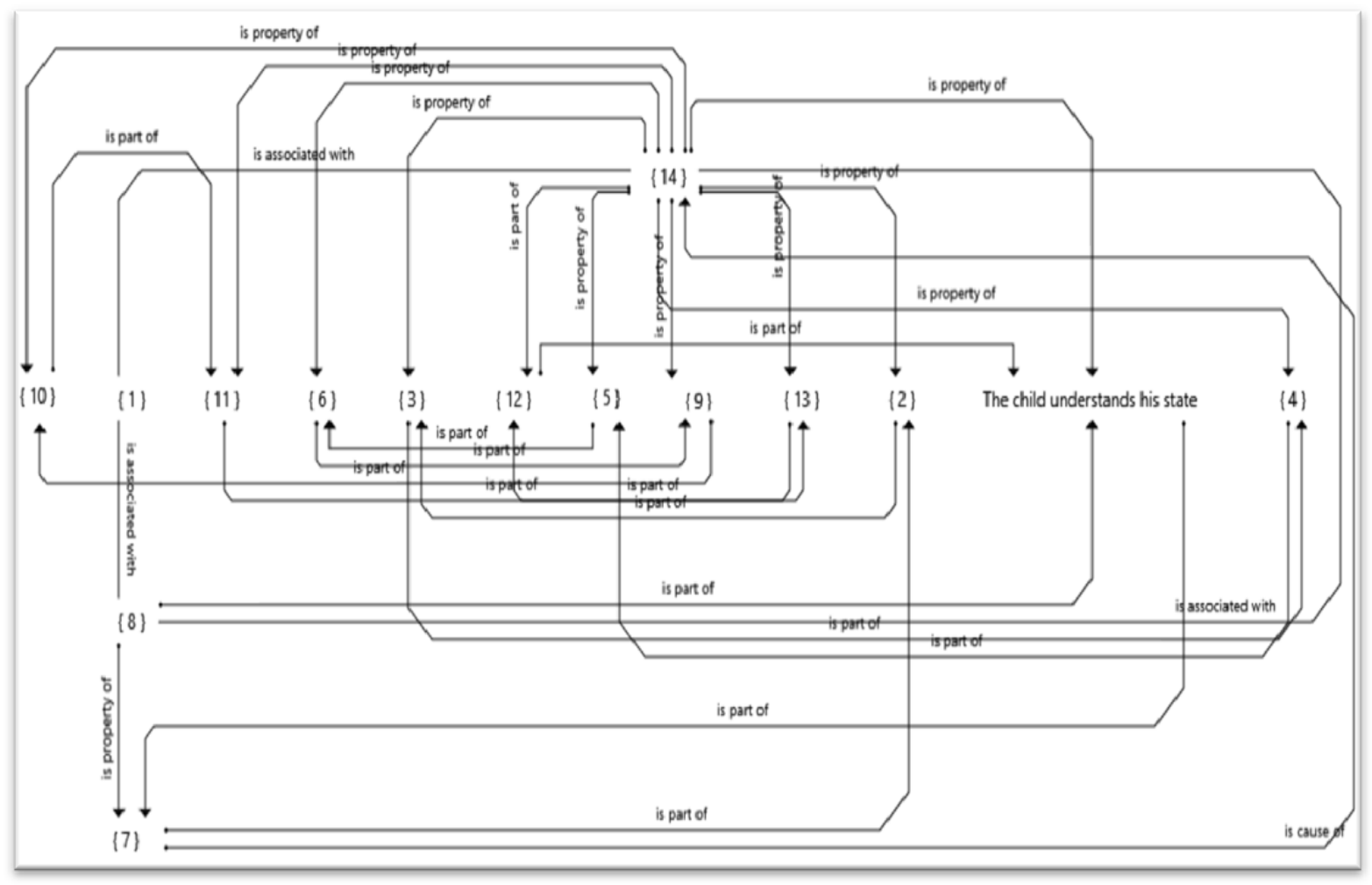

Figure 1. Actions to strengthen the autonomy of the child or minor in relation to care and communication to contribute to their understanding and care practices

Actions to strengthen autonomy and help care: $\{1\}$ : Contributes to the Strengthening of the Autonomy of the Child or Minor. $\{2\}$ : Greet the child. $\{3\}$ : Take care of the child's privacy. $\{4\}$ : Take care of the safety and integrity of the child. $\{5\}$ : Take care of the comfort of the child. $\{\mathbf{6}\}$ : Allows the child to express himself freely. $\{7\}$ : It allowed the active participation of parents in the child care process. $\{\mathbf{8}\}$ : Informed consent. $\{\mathbf{9}\}$ : Speak with the child from elements of both cognitive and affective empathy. $\{\mathbf{1 0}\}$ : Stimulates in the child the game and other ludic 
that contribute to their understanding of their state: $\{\mathbf{1 1}\}$ : The nurse uses a language adjusted to the child's moral development. $\{\mathbf{1 2}\}$ : Always treat the child by name. $\{\mathbf{1 3}\}$ : He asks the child about his condition continuously. $\{\mathbf{1 4}\}$ : Informed Assent. $\{\mathbf{1 5}\}$ : The child understands his state.

Diagramming which relates the analysis of the actions with the peripheral and central nodes: which respond to the five axioms from preferential links for which the co-occurrence analysis was used. (See Figure 2. Relationship of actions with peripheral nodes, central nodes and axioms of Paul Watzlawick).

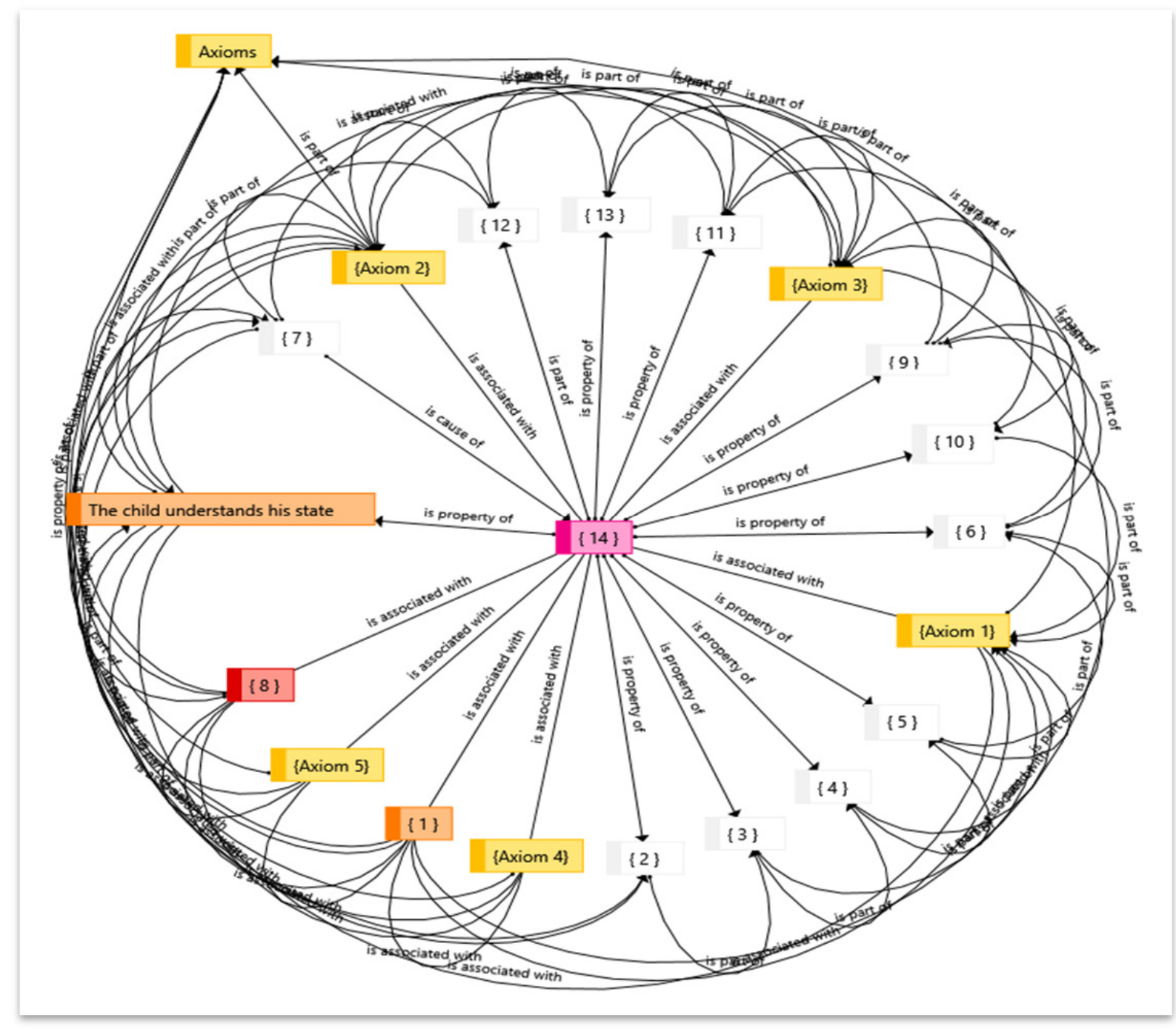

Figure 2. Relationship of actions with peripheral nodes, central nodes and axioms of Paul Watzlawick

Actions to strengthen autonomy and go to care:_\{1\}: Contributes to the Strengthening of the Autonomy of the Child or Minor. $\{2\}$ : Greet the child. $\{\mathbf{3}\}$ : Take care of the child's privacy. $\{4\}$ : Take care of the safety and integrity of the child. $\{\mathbf{5}\}$ : Take care of the comfort of the child. $\{\mathbf{6}\}$ : Allows the child to express himself freely. $\{7\}$ : It allowed the active participation of parents in the child care process. $\{\mathbf{8}\}$ : Informed consent. $\{\mathbf{9}\}$ : Speak with the child from elements of both cognitive and affective empathy. $\{\mathbf{1 0}\}$ : Stimulates in the child the game and other ludic that contribute to their understanding of their state: $\{\mathbf{1 1}\}$ : The nurse uses a language adjusted to the child's moral development. $\{\mathbf{1 2}\}$ : Always treat the child by name. $\{\mathbf{1 3}\}$ : He asks the child about his condition continuously. $\{\mathbf{1 4}\}$ : Informed Assent. \{15\}: The child understands his state. Axioms: $\{$ Axiom 1\}: It is impossible not to communicate. \{Axiom 2\}: Every communication has a content level and a relationship level, so that the latter classifies the first, and is therefore a meta-communication. \{Axiom 3\}: The nature of a relationship depends on the gradation that participants make of the communication sequences between them. \{Axiom 4\}: Human communication involves two modalities: digital and analog. \{Axiom 5\}: Communication exchanges can be both symmetric and 
complementary.

As a proposal of care and communication in pediatric, it was designed through the STATGRAPHICS Centurión ${ }^{\circledR}$ software in its process map function.

It was considered that all the actions that tend for positive aptitudes in the child are important as elements of social relation, conscious or not, what is intended is to make it intentional and logical, but mainly continue between a source and a receptor. In Watzlawick the elements of communication are determined by contingencies of relationship with a suitable and clear vocabulary, combined with emotions and feelings focused on an objective reality without exacerbating fear in the child, with the help of analogue and digital communication with an interactional approach between the child and the nurse. The informed consent was shown from the perception of the nurse as having little impact on the child directly, because the consent seeks to strengthen their autonomy, and informed consent the protection of the child by the tutor; supporting in the axiom number 5, because the child ceases to be an active agent of communication and care, to become a subject of asymmetry in communication relationship because it cries, screams or silenced, which disfavors the stability of communication between the nurse and the child or with the legal guardian.

The functional structure model arises from considering the central nodes as those that by their independent application manage to improve the positive attitude of the child, for example: take care of the comfort of the child, greet him by the name, adjust the language to comprehension and cognitive development of the child, as well as to consult him / her with any decision made regarding his/her health or illness (informed consent). These elements allow the child to form logical structures of empathy for health professionals and their situation does not become more traumatic to be away from their family or friends, as it allows them a deeper understanding of their status and hence power contribute to your self-care.

The model relates the analog actions that allow child to approach to the nurse free of intimidation. The edges of the nodes indicate the logic of hierarchical and synergistic structure of application from a common moral framework that is reflected in the following questions: How to greet without saying the name when they have been informed? How to allow free expression, without stimulating play and painting? How to consider that the child understands about his illness, when he is not allowed to search information and to be listened in a friendly and cordial way? (See Figure 3, Strategic model (Meso analysis)).

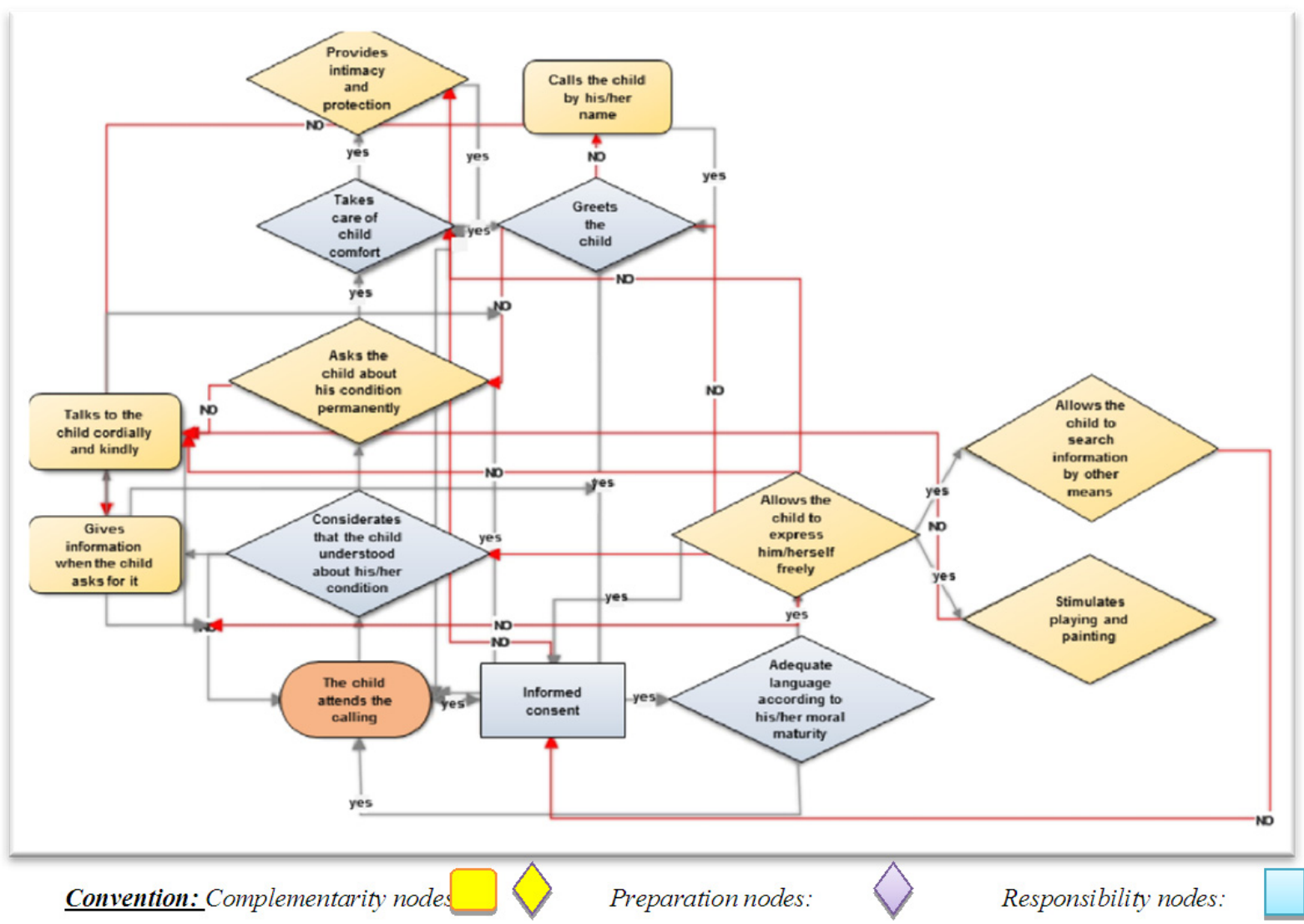

Figure 3. Strategic model (Meso analysis) 
The final model shows that in every process of nurse-patient relationship, it carries a network of symbologies that are represented and described on the axioms of Paul Watzlawick. From the proposed model, the elements represent axiological, teleological and deontological dimensions that the nurse must consider when promoting the well-being of the child (See Figure 4. Functional structure model for care and communication to pediatric patients).

$\checkmark$ Axiological elements. Each action of the nurse is immersed in: attention (care), empathy, truth, solidarity, compassion, tenderness.

$\checkmark$ Teleological Elements. The actions that directly or indirectly seek the welfare of the patient and the family defined by Aristotle as the "final cause since they are objects of love and desire" (Lloyd, 2007). In this frame of ideas is for example: stimulate as much as possible, according to patient's condition, playing and painting, to be cordial with the child and family, ask the child about their fears and anxieties, among other elements.

$\checkmark$ Deontological elements. They build good practices, which should dignify the care and therefore contribute to the development of child's autonomy, among these elements were: informed consent as a communication process, allow the search of information under the guidance or advice of a professional, provide privacy and protection, likewise; Consent as well as informed consent should help reduce anxiety and uncertainty on the child and family members.

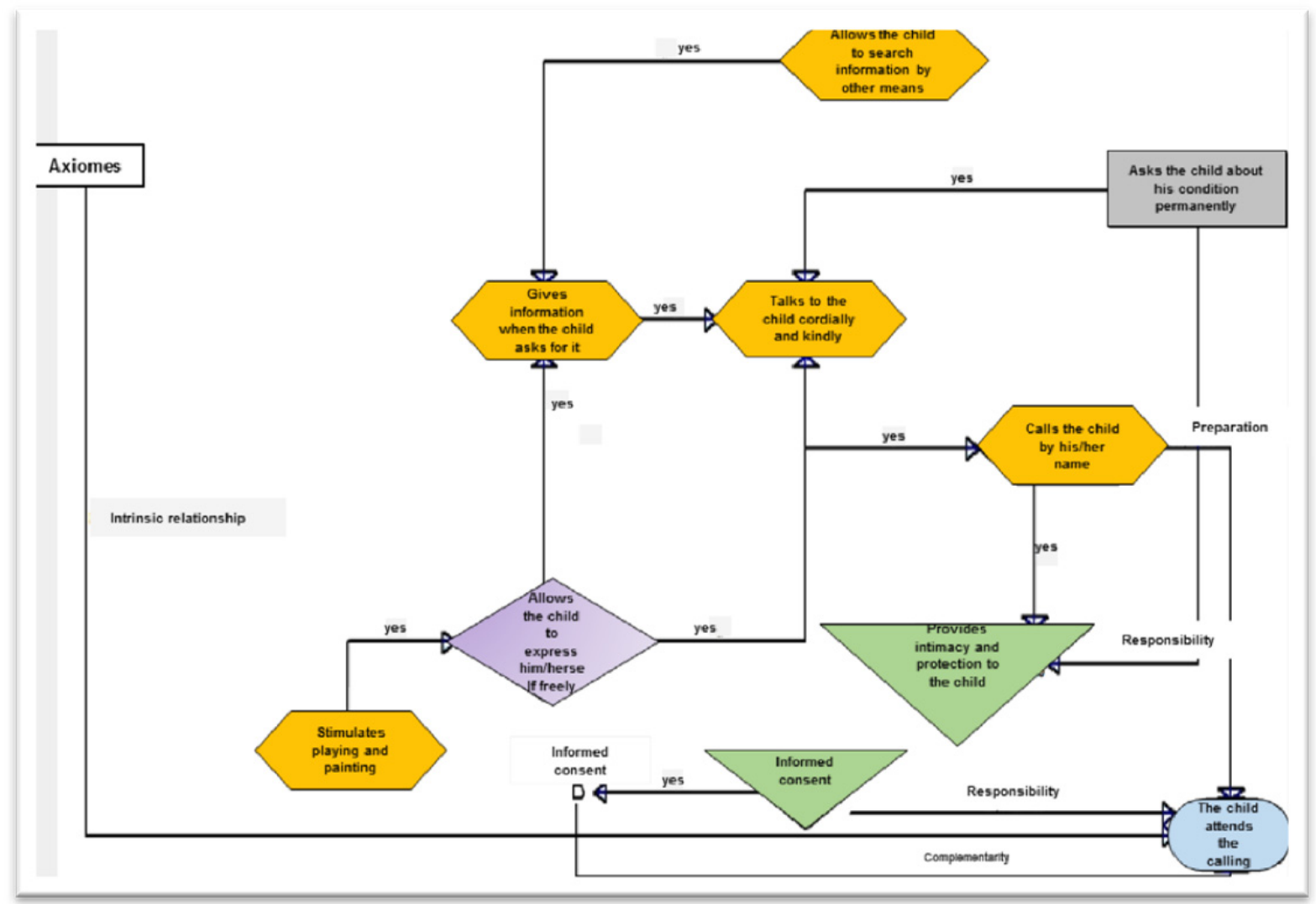

Figure 4. Functional structure model for care and communication to pediatric patients

These dimensions (axiological, teleological and deontological) project actions that enrich the nature of health professionals with a sense of humanization, expressed in the following activities, such as:

1) Psychological preparation activities for the child to go: Aristotle raises how to go to the call of a healthy life, a healthy body, a healthy apple, all say something different but that is understood as something in common that is the health "healthy", the call to seek health (Lloyd, 2007; Marías, 1970).

2) Responsibility activities: as a rule or duty of care in words described by Corinne Peluchón from Gilligan tend for: “. .. listen to their history and their pain, dialoguing in a relationship of emotional exchange where a certain 
vision of the world and values are shared" (Barra Almagia, 1987; Gilligan \& Utrilla, 1985; Lax, 2013; Shaffer \& Velázquez Arellano, 2000), that is to say, a symbology of actions and speeches.

3) Complementary activities: as the informed consent since it does not have a direct interference on the behavior or aptitude of the child towards his/her care, what is important to highlight is that the parent's tranquility will be perceived by the child.

4) Synergistic activities: as those that contribute to the preparation and responsibility activities are carried out in a logical and correct manner within a framework of moral management. (See Figure 4. Functional structure model for care and communication to pediatric patients)

\section{Discussion}

The axioms of communication proposed by Paul Watzlawick have a great relationship with several care theories proposed by nurses, for example, the theory of transpersonal care proposed by Watson, which allows us to understand why some practices of nurses, although they did not receive during their learning process lectures about communication theories, emerge in them these elements of humanized care as therapeutic communication, and likewise contributing to the moral development of the minor, calling the child by his/her name and allowing the expression of his emotions, which Watson defines as aiming an effective communication and interacting with the patient and family in a close way (J. Watson, 1979; M. J. Watson, 1988).

In the practices of nurses when caring for children, it was found that Watzlawick's axioms are immersed without a hierarchical structure, so the proposed functional structure model provides a logic in what can be understood by the health professional, as other studies expose, the axioms summed to theories parameters such as the ethics of care that provide the health professional with a metalanguage of what should be said, and how to care for the child (Watzlawick, 1977; Arango et al., 2016; Watzlawick \& Jackson, 2010).

Humanized care requires continuous thought about the elements of communication and social interaction, from the deontological, axiological and teleological dimensions as they were considered in the present investigation, in which beyond those actions or practices considered negative, such as not calling the child by his/her name, not allow him/her to play or express his fears; exposes that the axioms from a logical structure allow to understand a phenomenon little studied but very important in the framework of the pediatric attention (Pérez et al., 2014; Silver et al., 1967; Sobo, 2004; Well et al., 1993).

The proposed structural communication model focuses on the need to continue seeking strategies to achieve an assertive and empathetic communication that allows both children and parents and other family members a care focused on the needs of all the patient's dimensions, as for example cordial and kind treatment by the health professional, providing adequate and sufficient information with a comprehensible communication with principles of respect, trust, confidentiality, safety, among others (Oliveros-Donohue, 2015).

The informed consent / assent process is part of the communication system, which should contribute to the development of the child's autonomy, providing the necessary tools so that it can make its own decisions within a legal framework established by each country, which does not exempts the health professional from watching over moral elements that are constantly passed on to the minor, considering it as a subject without autonomy or in full development as an evolutionary stage to reach adulthood (Díaz-Pérez, Vega Ochoa, \& Romero Oñate, 2018).

\section{Conclusion}

The axioms proposed by Paul Watzlawick answer the questions of how care and communication should be considered to achieve the child's attention and cooperation. It is clear that the theoretical elements without a practice in the area of communication are a simple transmission of data, sometimes meaningless for both the transmitter and the receptor, since there is no purpose, which approached from the child and patient rights is to contribute to the dignity and well-being.

The methodological rigor of the functional structure model favors humanized care and improves communication, since one without the other is not perceived. The model could determine what elements are truly important in the relationship of the nurse and the pediatric patient, and what ethical values to relate to achieve the strengthening of the child's autonomy so that he/she approaches to the call of his/her care, as for example prudence, love, assertiveness, understanding, solidarity, among others; even pain, which is also a channel of communication from which information is abstracted.

It is not intended from the proposed model to consider the communication process as cause and effect (nurse gives an order and expects the child to comply), since Paul Watzlawick himself exposes it as a cyclic system, which does not mean that does not exist pragmatic conditions of relationship. 


\section{Competing Interests Statement}

The authors declare that there are no competing or potential conflicts of interest.

\section{References}

Arango, M. Z., Rodríguez, A. M., Benavides, M. S., \& Ubaque, S. L. (2016). Los axiomas de la comunicación humana en Paul Watzlawick, Janet Beavin, Don Jackson y su relación con la terapia familiar sistemica. Revista Fundación Universitaria Luis Amigó, 3(1), 33-50. https://doi.org/10.21501/23823410.1887

Bach, S., \& Grant, A. (2015). Communication and interpersonal skills in nursing. Learning Matters.

Barra Almagia, E. (1987). El desarrollo moral: una introducción a la teoría de Kohlberg. Revista Latinoamericana de psicología, 19(1).

Bautista, C. (2011). Proceso de la investigación cualitativa: Epistemología, metodología y aplicaciones. Manual Moderno.

Bonill de las Nieves, C. (2008). La importancia de las habilidades comunicativas en la humanización de los cuidados. Index de Enfermería, 17(1), 74-75. https://doi.org/10.4321/S1132-12962008000100017

de Villalobos, D., \& Mercedes, M. (2005). La ciencia, la ética y el arte de enfermería a partir del conocimiento personal. Aquichan, 5(1), 86-95.

Diaz-Perez, A., Fernández Aragón, S. P., Díaz Narváez, V. P., Fernández Beleño, A., Navarro-Quiroz, E., \& Mendoza Cataño, C. L. (2018). Empathy in the Curriculum for Patient Care.

Díaz-Pérez, A., Vega Ochoa, A. D., \& Romero Oñate, Z. (2018). The Informed Consent/Assent from the Doctrine of the Mature Minor.

Fellowes, D., Wilkinson, S., \& Moore, P. (2008). Entrenamiento en habilidades comunicativas para los profesionales de la asistencia sanitaria que trabajan con pacientes con cáncer, sus familias o cuidadores (Revisión Cochrane traducida). La Biblioteca Cochrane Plus, (2).

García, A. A. (2004). La ética del cuidado. Aquichan, 4(4), 30-39. Universidad de La Sabana.

Garcia Reza, C., Iniesta, C., del Carmen, M., Solano Solano, G., \& Guadarrama Perez, R. (n.d). El placer de cuidar: relato de las enfermeras quirúrgicas.

García-Salido, A., la Calle, G. H., \& González, A. S. (2018). Revisión narrativa sobre humanización en cuidados intensivos pediátricos:?’ dónde estamos? Medicina Intensiva. https://doi.org/10.1016/j.medin.2018.01.006

Gilligan, C., \& Utrilla, J. J. (1985). La moral y la teoría: psicología del desarrollo femenino. Fondo de Cultura Económica Mexico.

Lax, A. M. (2013). La ética de la vulnerabilidad de Corine Pelluchon. Daimon Revista Internacional de Filosofia, (58), 171-178.

Lloyd, G. E. R. (2007). Aristóteles. Prometeo Libros Editorial.

Maldonado, A. D. A. (2012). La comunicación en la relación de ayuda al paciente en enfermería:: saber qué decir y qué hacer. Revista Española de Comunicación en Salud, 3(2), 147-157.

Marías, J. (1970). Ética a Nicómaco de Aristóteles. Madrid: Instituto de Estudios Políticos.

Mella, O. (1998). Naturaleza y orientaciones teórico-metodológicas de la investigación cualitativa. Santiago: CIDE, 51 .

Oliveros-Donohue, M. Á. (2015). Humanización de la Pediatría. Acta Médica Peruana, 32(2), 85-90.

Pérez, A. D., Puerta, Z. B., \& Cataño, C. M. (2014). Cuidado y comunicación por parte de enfermeros a familiares de pacientes hospitalizados en una unidad de cuidados intensivos. Cultura del Cuidado Enfermeria, 11(2), 17-31.

Riley, J. B. (2015). Communication in nursing. Elsevier Health Sciences.

Shaffer, D. R., \& Velázquez Arellano, J. A. (2000). Psicología del desarrollo: infancia y adolescencia.

Sheldon, L. K., Barrett, R., \& Ellington, L. (2006). Difficult communication in nursing. Journal of Nursing Scholarship, 38(2), 141-147. https://doi.org/10.1111/j.1547-5069.2006.00091.x

Silver, H. K., Ford, L. C., \& Steady, S. G. (1967). A program to increase health care for children: the pediatric nurse practitioner program. Pediatrics, 39(5), 756-760. 
Sobo, E. J. (2004). Pediatric nurses may misjudge parent communication preferences. Journal of nursing care quality, 19(3), 253-262. https://doi.org/10.1097/00001786-200407000-00012

Torres, L. C., \& Campos, M. G. (2010). La empatía, un sentimiento necesario en la relación enfermera-paciente. Desarrollo Cientif Enferm (Méx), 18(3), 120-4.

Tseng, Y.-H., Weng, C.-S., Kuo, S.-H., Chou, F.-H., Yang, Y.-H., \& Chiang, L.-C. (2015). Gender Differences? Internet use and parent-child communication about sex toward sexual attitudes among early adolescents in Taiwan. Journal of Nursing Research, 23(2), 125-134. https://doi.org/10.1097/jnr.0000000000000067

Velásquez, S. T. (2017). De la ética del cuidado de sí a la propuesta crítica en foucault. Ratio Juris, 3(7), 67-75. https://doi.org/10.24142/raju.v3n7a7

Watson, J. (1979). Nursing: The philosophy and science of caring. Nursing administration quarterly, 3(4), 86-87. https://doi.org/10.1097/00006216-197900340-00010

Watson, M. J. (1988). New dimensions of human caring theory. Nursing science quarterly, 1(4), 175-181. https://doi.org/10.1177/089431848800100411

Watzlawick, P. (1977). How real is real?: confusion, desinformation, communication. New York.

Watzlawick, P., Bavelas, J. B., \& Jackson, D. D. (2011). Pragmatics of human communication: A study of interactional patterns, pathologies and paradoxes. WW Norton \& Company.

Watzlawick, P., \& Jackson, D. D. (2010). On human communication (1964). Journal of Systemic Therapies, 29(2), 53-68. https://doi.org/10.1521/jsyt.2010.29.2.53

Well, E., First, F., Dignity, P., it Out, W., \& Training, C. B. (1993). Children's consent to surgery. Paediatric Nursing, 3(10).

\section{Copyrights}

Copyright for this article is retained by the author(s), with first publication rights granted to the journal.

This is an open-access article distributed under the terms and conditions of the Creative Commons Attribution license (http://creativecommons.org/licenses/by/4.0/). 